\title{
ENTREPRENEURIAL PERFORMANCE CONSTRUCT, ITS DIMENSIONS, MEASURES AND ISSUES
}

\author{
Rita Subedi ${ }^{*}$
}

\begin{abstract}
Entrepreneurial performance is a construct evolved from organizational theory and strategic management. It is extensively researched and discussed to define venture success or failure in entrepreneurship domain. However, there is lack of consensus between scholars to choose measures and data sources used to identify the behavior of entrepreneurial performance construct. Due to this they have been facing considerable difficulty to choose accurate and adequate performance measure which is critical to consistent results. Present paper reviews existing literature focusing on entrepreneurial performance construct and its measurements. The purpose of this paper is to identify current position regarding the entrepreneurial performance construct and its measurements and issues. The existing literature related to measurements of entrepreneurial performance were reviewed. The results depicted that vast majority of the studies have considered unidimensional measures especially financial measures as core which covers mostly efficiency, profit and growth dimensions. Very few studies have considered operational, and stakeholder satisfaction dimensions. As like as measures, most of the studies, (more than 75 percent) were used primary data, very few studies were used secondary and triangulated data source. This leads the inaccuracy in results.
\end{abstract}

Key works: Entrepreneurial performance construct, measurements, triangulated data source, organizational performance

\section{Introduction}

Entrepreneurial performance refers the act of performing or execution or accomplishment of work or entrepreneurial success/failure or entrepreneurial outcome. It is also concerned with accomplishment of entrepreneurial goals by exploiting designed mechanism and available resources. Entrepreneurial performance is defined as 'the achieving of set entrepreneurial goals' (Van Vuuren, 1997); entrepreneurial performance utilizes the available opportunities to grow the business, (Ladzani, \& Van Vuuren, 2002). Performance is a yardstick by which the founder measures success (Hanks, 1994). The entrepreneurial performance construct has been using interchangeably to identify new venture survival, growth and success of business organization in entrepreneurship domain.

The performance construct mostly studied in organization theory and strategic management, (Myint, 2016). The organization theory has indicated three approaches to measure organizational performance. They are goal-based approach, system approach and constituency approach. The

* Assistant Professor of Saraswati Multiple Campus (Management Faculty), Tribhuvan University, Nepal 
goal-based approach discusses the organizations can be assessed based on the goals they set (Etzioni, 1964). The system approach noted the simultaneous achievement of multiple, and generic performance aspects must also be considered (Steers, 1975). The constituency approach came to examine the extent to which the schedule of various shareholder groups is satisfied (Thompson, 1967; Pfeffer \& Salancik, 1978).

The strategic management also integrates three organization theoretic approach, which includes various hierarchical constructs having different measurements. They are financial performance construct, operational performance construct, and constructs based on two dimensions, first one financial versus operational measures, and second based on primary versus secondary data sources used for gaining data of each indicator (Venkatraman \& Ramanujam, 1986).

They have also distinguished between financial and nonfinancial performance measures into objective and subjective measures of performance based on the feature they possess. Such as the objective dimension has a quantifiable (physical or observable) attribute. It may be considered as a subjective dimension or perceived dimension and individuals evaluate the objects based on perception. In contrast of objective dimension, the perceived dimension is the individual's interpretation that may or may not be based on objective dimension (Hair et al. 2010). Moreover, the subjective measures are typically described as perceptual that provide a relative assessment of performance (i.e., as compared with competitors) rather than exact numerical values (Dess \& Robinson, 1984).

The other distinction between performance measurements is financial versus non-financial measures. The financial measures include items such as sales growth, return on asset and nonfinancial indicators include satisfaction and global success ratings made by owners or business managers (Rauch et al. 2009). On the basis of these differences in financial and non-financial performance they further categorized performance dimension as archival financial performance, perceived financial performance, nonfinancial performance and perceived nonfinancial performance. They suggested that both financial and non-financial measures could be described when measuring performance.

Among performance measures stated above the financial performance construct is located at the core of organizational effectiveness dimension. Although it is considered as essential, but not yet sufficient (i.e. Chakravarthy, 1986). The operational performance construct is also considered as a "beyond the core" measure of performance which considers indicators such as market share that ultimately led to financial performance (Kaplan, 1983; Murphy et al., 1996). Thus, Venkatraman and Ramanujam, (1986) suggested that both operational dimensions and financial dimensions should be investigated while studying the performance of the organization. Several other scholars also have noted the importance of using multiple measures of the dimension of performance (Kaplan,1973, Gupta, 1987, Steers, 1975, Randolph, Sapienza and Watson,1991).

Entrepreneurial performance construct has been measuring by the multidimensional scales as stated in the literature of organizational performance. However, there is lack of consensus between scholars to choose performance measures. Due to this entrepreneurship scholars have been facing considerable difficulty to choose accurate, and adequate measures of performance construct and data source, which is critical to obtained accurate results (Myint,2016). 
To meet this gap present paper reviews existing literature focused on entrepreneurial performance construct and its measurements. The purpose of this paper is to identify current position regarding the performance dimensions, measures and data source used. The rationale for this is that evaluation of dimensions, measures and data sources helps future researcher to make an understanding about current practice and also helps to broaden the knowledge of entrepreneurship domain. The paper follows initially introduction of entrepreneurial performance construct, after which reviews the performance dimensions, measures and data sources used in the existing literature studies with controversy issues and finally presents discussion and conclusion.

\section{Dimensions and measurements}

There are several dimensions and measures have developed under three dimensions as stated above for measuring entrepreneurial performance construct. In the review of measuring performance in entrepreneurship research Murphy, (1986) have found eight performance dimensions. They are presented in table 1.

\begin{tabular}{lc}
\hline \multicolumn{1}{c}{ Dimensions } & Frequency \\
\hline Efficiency & 30 \\
Growth & 29 \\
Profit & 26 \\
Size & 15 \\
Liquidity & 9 \\
Success/Failure & 7 \\
Market share & 5 \\
Leverage & 3 \\
\hline
\end{tabular}

Source: Murphy, (1996)

Moreover, another review of performance measurement in entrepreneurship conducted by Myint, (2016) have found 7 dimensions. Out of total 2 dimensions are new i.e., stakeholder satisfaction with overall performance and reputation. They are presented in table 2 with their frequency of use in the sample study.

Table:2 Performance dimensions with Frequency

\begin{tabular}{lc}
\hline \multicolumn{1}{c}{ Dimensions } & Frequency \\
\hline Growth & 32 \\
Profit & 15 \\
Efficiency & 13 \\
Liquidity & 8 \\
Market share & 6 \\
Satisfaction of stakeholder & 5 \\
with overall performance & \\
Reputation & 1 \\
\hline
\end{tabular}


Source: Myint, (2016)

There is altogether 10 dimensions have shown in table 1 and 2 . Table 1 shows efficiency is a frequently used dimension (i.e., 30 out of 51) in sample article. Table 2 shows growth is a dimension having high frequency (32 out of 51). They all either growth and efficiency or profit, size, and liquidity are representing financial measures. The operational dimension i.e., market share and the satisfaction dimension i.e., stakeholder satisfaction dimension both are in lower frequency i.e., 5. The data stated in table 1 and 2 shows financial dimension is frequently used dimension in entrepreneurial performance literature.

The measures which are frequently used in the study of entrepreneurial performance construct, they have found under 10 dimensions are presented in table 3 .

Table 3: Measurements and their frequency

\begin{tabular}{|c|c|c|c|c|}
\hline Dimensions & Measures & Frequency & Measures & Frequencies \\
\hline \multirow[t]{5}{*}{ Efficiency } & Return on Investment & 13 & $\begin{array}{l}\text { Average return on } \\
\text { assets }\end{array}$ & 2 \\
\hline & Return on Assets & 9 & $\begin{array}{l}\text { Net sales to total } \\
\text { capital }\end{array}$ & 1 \\
\hline & Return on Equity & 9 & $\begin{array}{l}\text { Return on average } \\
\text { equity }\end{array}$ & 1 \\
\hline & Return on net worth & 6 & $\begin{array}{l}\text { Internal rate of } \\
\text { return }\end{array}$ & 1 \\
\hline & $\begin{array}{l}\text { Gross revenue per } \\
\text { employee }\end{array}$ & 3 & $\begin{array}{l}\text { Relative product } \\
\text { cost }\end{array}$ & 1 \\
\hline \multirow[t]{6}{*}{ Growth } & Change in sales & 23 & Job generation & 1 \\
\hline & Change in employee & 5 & Company birth & 1 \\
\hline & Market share growth & 2 & $\begin{array}{l}\text { Change in present } \\
\text { value }\end{array}$ & 1 \\
\hline & $\begin{array}{l}\text { Change in net income } \\
\text { margin }\end{array}$ & 2 & $\begin{array}{l}\text { Number of } \\
\text { acquisitions }\end{array}$ & 1 \\
\hline & $\begin{array}{l}\text { Change in CEO/Owner } \\
\text { compensation }\end{array}$ & 2 & $\begin{array}{l}\text { Change in pretax } \\
\text { profit }\end{array}$ & 1 \\
\hline & $\begin{array}{l}\text { Change in labor expenses } \\
\text { in revenue }\end{array}$ & 1 & Loan growth & 1 \\
\hline \multirow[t]{4}{*}{ Profit } & Return on sales & 11 & $\begin{array}{l}\text { Stock price } \\
\text { appreciation }\end{array}$ & 1 \\
\hline & Gross profit margin & 7 & Price to earnings & 1 \\
\hline & Net profit margin & 8 & $\begin{array}{l}\text { Respondents' } \\
\text { assessment }\end{array}$ & 1 \\
\hline & Net profit level & 5 & Earnings per share & 1 \\
\hline
\end{tabular}




\begin{tabular}{|c|c|c|c|c|}
\hline & Net profit from operation & 5 & $\begin{array}{l}\text { Average return on } \\
\text { sales }\end{array}$ & 1 \\
\hline & Pretax profit & 3 & $\begin{array}{l}\text { Average net profit } \\
\text { margin }\end{array}$ & 1 \\
\hline & $\begin{array}{l}\text { Clints estimates of } \\
\text { incremental profit }\end{array}$ & 1 & $\begin{array}{l}\text { Market to book } \\
\text { value }\end{array}$ & 1 \\
\hline \multirow[t]{7}{*}{ Size/Liquidity } & Sales level & 13 & $\begin{array}{l}\text { Number of } \\
\text { employees }\end{array}$ & 5 \\
\hline & Cash flow level & 6 & Cash flow to sales & 1 \\
\hline & Ability to fund growth & 5 & $\begin{array}{l}\text { Inventory } \\
\text { turnover }\end{array}$ & 1 \\
\hline & Current ratio & 2 & $\begin{array}{l}\text { Account } \\
\text { receivable } \\
\text { turnover }\end{array}$ & 1 \\
\hline & Quick ratio & 2 & $\begin{array}{l}\text { Cash flow to total } \\
\text { debt }\end{array}$ & 1 \\
\hline & Total assets turnover & 1 & $\begin{array}{l}\text { Working capital } \\
\text { to sales }\end{array}$ & 1 \\
\hline & Cash flow to investment & 1 & $\begin{array}{l}\text { Operating under } \\
\text { court order }\end{array}$ & 1 \\
\hline \multirow[t]{4}{*}{ Success/Failure } & Discontinued business & 4 & $\begin{array}{l}\text { No new telephone } \\
\text { number }\end{array}$ & 1 \\
\hline & $\begin{array}{l}\text { Researcher's subjective } \\
\text { assessment }\end{array}$ & 1 & Salary of owner & 1 \\
\hline & Return on net worth & 1 & $\begin{array}{l}\text { Change in gross } \\
\text { earning }\end{array}$ & 1 \\
\hline & $\begin{array}{l}\text { Respondents' subjective } \\
\text { assessment }\end{array}$ & 1 & & \\
\hline \multirow[t]{2}{*}{ Market Share } & Respondent assessment & 3 & PIMS values & 1 \\
\hline & $\begin{array}{l}\text { Firm product sale to } \\
\text { industry product sale }\end{array}$ & 1 & & \\
\hline \multirow[t]{2}{*}{ Leverage } & Debt to equity & 2 & $\begin{array}{l}\text { Long term debt to } \\
\text { equity }\end{array}$ & 1 \\
\hline & Time interest earn & 1 & $\begin{array}{l}\text { Stockholders' } \\
\text { capital to total } \\
\text { capital }\end{array}$ & 1 \\
\hline $\begin{array}{l}\text { Satisfaction of } \\
\text { stakeholder } \\
\text { with overall } \\
\text { performance }\end{array}$ & $\begin{array}{l}\text { Profit satisfaction (return } \\
\text { on investment, return on } \\
\text { equity, return on assets, } \\
\text { net profit margin) } \\
\text { Growth Satisfaction }\end{array}$ & 5 & & \\
\hline
\end{tabular}


(Sales growth, growth in number of employees, market share growth)

$\begin{array}{ll}\text { Reputation } & \text { The business's } \\ \text { international reputation }\end{array}$

Others

Change in employee
turnover

1

Relative quality 1

Dependents in corporate 1 sponsor

Source: Murphy, et.al., (1996) and Myint, (2016)

Total 74 measures of performance are observed under 10 dimensions in table 3 . The vast majority of performance measures related to one of performance dimension i.e., financial dimension. The two measure from operational dimension is market share and reputation and two measures from stakeholder satisfaction dimension are profit satisfaction and growth satisfaction. The result shows that entrepreneurial performance is mostly measured by financial dimension including the measures of efficiency, profits, growth and size. They are mostly unidimensional. This finding is inconsistent with organization performance literature i.e., performance studies most be multidimensional for accurate result.

As like as dimensions and measures, the data source used for the study of entrepreneurial performance have found variance among the studies. Out of total (51 articles) $75 \%$ sample article have considered primary data sources (i.e., questionnaire- interview), 29\% have considered secondary data sources (i.e., archival data source), and only $6 \%$ have considered both (i.e., mixed/triangulated data source) (Murphy, et.al., 1996). Another study conducted by Myint, (2016) stated that $60 \%$ sample article (51 articles) have considered primary data sources, $26 \%$ have used secondary data sources and $14 \%$ have used both (mixed/triangulated).

\section{Issues}

There are three major issues arising in the study of entrepreneurial performance. They are i) issue related to dimensionality, ii) issue related to data sources and iii) issue related to subjectivity and objectivity.

The first issue is concerned with the question that which dimensions and measures are important to be considered in the study of entrepreneurial performance. Only financial, both financial and operational, or financial, operational and stakeholder satisfaction. The second issue is concerned with the question that which data sources used to measure entrepreneurial performance. Only primary, only secondary or both primary and secondary. The third issue is concerned with accuracy of subjectivity and objectivity. 


\section{Discussion and conclusion}

Performance construct in general is extensively researched to measure success of organizations. Entrepreneurial performance is not expectation. The accuracy and adequacy in measurements is critical to identify organizational success/ failure. Existing literature related to organizational performance measurement suggested that use of multiple measures form multiple dimensions will be near to accuracy and adequacy. However, vast majority of the studies in entrepreneurial performance studies are used unidimensional measures i.e., efficiency, profit, growth, liquidity, and size. The measures form operational and stakeholder satisfaction dimension are rarely in practice. Organizational performance literature does support multidimensional measures for accuracy of result. As like as measures, most of the entrepreneurial performance studies are conducted by using only primary data. Entrepreneurial performance measured by using only primary data covers only the subjectivity of performance. Without objectivity from archival data the study will be far from accuracy. Thus, entrepreneurship scholars should be used multidimensional scales to measure entrepreneurial performance.

\section{References}

Chakravarthy, B. S. (1986). Measuring strategic performance. Strategic management journal, $7(5), 437-458$.

Dess, G. G., \& Robinson, R. B., (1984). Measuring organizational performance in the absence of objective measures: the case of the privately• held firm and conglomerate business unit. Strategic management journal, 5(3), 265-273.

Dess, G. G., \& Robinson, R. B. (1984). Measuring organizational performance in the absence of objective measures: the case of the privately held firm and conglomerate business unit. Strategic management journal, 5(3), 265-273.

Etzioni, A., (1964). Modern Organizations, Prentice-Hall, Englewood Cliffs, NJ.

Fernhaber, S. A., \& Li, D. (2010). The impact of interorganizational imitation on new venture international entry and performance. Entrepreneurship Theory and Practice, 34(1), 1-30.

Gupta, A., (1987). SUB Strategies, Corporate SUB Relations and SUB effectiveness in strategy implementation. Academy of Management Journal. 30, 477-500.

Hair, J., Black, W., Babin, B., and Anderson, R. (2010). Multivariate data analysis (7th ed.): Prentice-Hall, Inc. Upper Saddle River, NJ, USA.

Kaplan, R.S. (1983). Measuring Manufacturing Performance: A new challenges for Managerial Accounting Research, The accounting Review,55,686-705.

Murphy, G. B., Trailer, J. W., \& Hill, R. C. (1996). Measuring performance in entrepreneurship research. Journal of Business Research, 36(1), 15-23.

Pfeffer, J., \& Salancik, G., (1987). The External Control of Organizations, Harper \& Row, New York. 
Randolph, W. Alan, Sapienza, Harry J. and Watson, M.A., (1991). Technology-structure fit and performance in Small Business: An examination of moderating effects of organizational states. Entrepreneurship theory and practice, 27-41

Rauch, A., Wiklund, J., Lumpkin, G. T., \& Frese, M. (2009). Entrepreneurial orientation and business performance: An assessment of past research and suggestions for the future. Entrepreneurship Theory and Practice, 33(3), 761-787.

Steers, R. M. (1975). Problems in the measurement of organizational effectiveness. Administrative Science Quarterly, 546-558.Pfeffer, Jeffrey, and Salancik, Gerald, (1978).The External Control of Organizations, Harper \& Row, New York.

Thompson, James D. (1967).Organizations in Action, McGraw Hill, New York.

Venkataraman, N. \& Ramanujam, V. (1985). Construct Validation of Business Economic Performance Measures: A Structural Equation Modeling Approach, BEBR, Faculty Working Paper No.1148, College of commerce and Business Administration, University of Illinois.

Venkatraman, N. \& Ramanujam, V. (1986). Measurement of business performance in strategy research: A comparison of approaches. Academy of Management Review, 11, 801-814.

Van Vuuren, J.J., (1997). Entrepreneurship education and training: a prospective content model, proceeding of the $8^{\text {th }}$ Annual Entrepreneurship East Meets West World Conference (ENDEC), Los Angeles,4-6 September, 591-600. 